\title{
An Evaluation of Clinical Learning Experience among Fourth-year Nursing Students of Nueva Ecija University of Science and Technology
}

\author{
George M. Rivera ${ }^{1}$, Thea Irise M. Eugenio ${ }^{2}$, Romar M. Bendiola ${ }^{3}$, Marie Denise M. Esguerra ${ }^{4}$, Kelvin \\ Mark P. Quetua ${ }^{5}$, Danylen Felyze G. Paras ${ }^{6}$, Leinus Karl P. Santiago ${ }^{7}$, Divina B. Ocampo ${ }^{8}$, \\ Zuzette B. Catabona9 \\ 1,2,3,4,5,6,7,8,9 Nueva Ecija University of Science and Technology, Philippines
}

\section{ARTICLE INFO}

Article history:

DOI:

10.30595/pshms.v2i.221

Submitted:

December 6, 2021

Accepted:

January 21, 2022

Published:

January 26, 2022

\section{Keywords:}

Clinical learning environment; clinical learning experience; core competencies; undergraduate nurses; evaluation

\begin{abstract}
The clinical learning environment is an essential component of nursing education as it allows students to integrate theory into clinical practice. However, it is considered a critical factor as it may or may not help the student nurses grow and expand their knowledge, skills, and professional attitude. As such, this study described the clinical learning experience of the fourth-year nursing students of Nueva Ecija University of Science and Technology examining the underlying factors that influence the entire learning experience. The study utilized a descriptive - quantitative correlational design and total enumeration as the sampling procedure. The result showed that most of the respondents were in the early adulthood; female; monthly family income is 5,001-10,000, and preferred working in base hospital, operating room; and preferred the morning shift. The core competencies in which the respondents showed enhanced performance and aptitude were legal responsibility, ethico-moral responsibility, and collaboration and team work. The lowest, on the other hand, were personal and professional development, quality improvement, safe and quality nursing care, and research. A significant relationship between the actual age and safe and quality nursing and communication core competencies. A proposed action plan was devised for student nurses to strengthen their research competency.
\end{abstract}

This work is licensed under a Creative Commons Attribution 4.0 International License.

\section{Corresponding Author:}

George M. Rivera,

Nueva Ecija University of Science and Technology,

Gen. Tinio Street, Cabanatuan City, Philippines

Email: mgeorge.rivera@gmail.com

\section{INTRODUCTION}

Clinical Learning Environment (CLE) is clearly defined in the nursing framework as an interacting network of variables inside the clinical context that impacts students' learning outcomes. CLE has five components namely: pedagogical atmosphere on the ward, supervisory relationship, leadership style, premises of nursing, and role of the nurse teacher [1].

Students' exposure to clinical environment plays a huge role in the teaching-learning mechanism. Research has found out that learning environments is regarded as one of the fundamental elements that influence the aptitude of students [2].

However, newly graduated nurses with lacking nursing training are afraid to make mistakes in a lifethreatening situation [3]. The lack of opportunity to perform clinical practice is the biggest problem in terms of the confidence of student nurses to perform core clinical skills. Therefore, enhanced educational strategies and knowledge applications should be utilized to increase confidence and knowledge to perform clinical skills and their competence in utilizing nursing process. 
In addition, a research study done in Oman on student nurses' satisfaction with and effectiveness of the learning experience found that satisfaction with the CLE sub-dimensions was highly essential and had a positive relationship with the overall clinical learning environment [4]. In contrast, a study found that the function of the clinical teacher in clinical practice had the lowest mean rate [5].

It has been shown that students who study in a supportive learning environment are more inspired, engaged, and have higher overall learning potential. Students, on the other hand, studying in bad settings with unpleasant, noisy, and full of distractions, will find it much harder to consume data and remain engaged [6].

Hence, this research study aimed to evaluate the clinical learning environment fostered by the NEUST and its affiliated hospitals by identifying the demographic profile, clinical hospital assignment, core competencies, and clinical learning experience of fourth-year student nurses. With this, the teaching modalities implemented by the institution and the clinical instructors' performance in the clinical setting are evaluated based on the results of the respondents' experiences. Thus, determining the institution's performance in terms of delivering a highly competitive and learning-conducive clinical learning environment for its students.

\section{RESEARCH METHOD}

This study utilized a descriptive - quantitative correlational design and total enumeration as the sampling procedure. This was conducted in Nueva Ecija University of Science and Technology at General Tinio, Cabanatuan City, Nueva Ecija during the months of January to May 2021, gathering data from level four student nurses as respondents. The researchers chose the Level Four students as the respondents because they hold vast exposure to clinical settings compared to that of other year levels. Inclusion criteria includes a total of 1148 clinical hours and under the CHED Memorandum Order No. 14 (CMO No.14) curriculum, which agreed with the core competencies that were used in the questionnaire. Thus, the researchers contemplated that they were the most suited individuals to participate in the study. Students that did not meet the aforementioned criteria are excluded from the respondent population.

The instrument used in this study contains the following sections: (1) Demographic profile that includes age, sex, and monthly family income; (2) Clinical Hospital Assignment that involves affiliated hospitals, area of clinical rotation, and duty schedule; (3) Core Competencies adapted from CHED Memorandum Order (CMO) no. 14 which include safe and quality nursing care, management of resources and environment, communication, collaboration and teamwork, health education, legal responsibility, ethicomoral responsibility, personal and professional development, quality improvement, research, and records management; and (4) Clinical Learning Environment (CLE) that consists of pedagogical atmosphere on the ward, supervisory relationship, the leadership skills of student nurses in peers, nursing care in the ward, and clinical instructor relationship. For data analysis, the sample means, frequency, distribution, and Pearson's $r$ Correlation were used to find significant relationship of demographic profile to core competencies and clinical learning experience.

The researchers observed ethical considerations, reviewed and checked by the research board, to promote the goals and objectives of the research itself, support the social and moral principles, and secure the values of individuals involved in the research study. The researchers ensured that no respondents were coerced, deceived, or harmed in participating in the study. Data collection was done after the respondents were informed about the research objectives and signed the consent form. Also, the researchers assured the respondents to implement data privacy and confidentiality.

\section{RESULT AND DISCUSSIONS}

Table 1. Frequency Distribution of Fourth-year nursing students characteristics at NEUST ( $\mathrm{n}=15)$

\begin{tabular}{lcc}
\hline \multicolumn{1}{c}{ Characteristic } & Frequency & Percentage \\
\hline Age & 8 & 53.3 \\
$21-25$ & 4 & 26.7 \\
$26-30$ & 3 & 20.0 \\
$31-35$ & & \\
Sex & 12 & 80.0 \\
$\quad$ Female & 3 & 20.0 \\
Male & & \\
Family Monthly Income & 0 & 0 \\
0-5,000 & 8 & 53.3 \\
$5,001-10,000$ &
\end{tabular}

Proceeding homepage: https://conferenceproceedings.ump.ac.id/index.php/pshms/issue/view/10 


$\begin{array}{ccc}10,001-20,000 & 4 & 26.7 \\ 20,001-30,000 & 1 & 6.7 \\ 30,001-40,000 & 2 & 13.3\end{array}$

Based on table 1, it is known that there are 15 respondents (100\%), showing that most respondents are between the ages of 21-25 with 8 nursing students $(53.3 \%)$ and most of the respondents are female amounting to $12(80 \%)$. The small quantity of respondents is the result of the K-12 implementation in the Philippine education system that adds two more years in high school which occurred in the school year 20122013[7]. The enrollees are students who belong in the old curriculum and are returning to college to pursue their undergraduate studies, thus resulting to low enrolment rate. Meanwhile, the majority of respondents have a family income between Php 5,001-10,000 consisting of 8 respondents (53.3\%). This is included in the demographic parameters to identify whether financial capability is a critical factor in enhanced clinical learning experience. Since it was argued that a higher income family promotes better learning outcomes as tools, books, and gadgets effective for learning are fulfilled [8].

Table 2. Frequency Distribution of Fourth-year nursing students' clinical hospital assignment at NEUST

\begin{tabular}{|c|c|c|}
\hline $\begin{array}{c}\text { Clinical Hospital } \\
\text { Assignment }\end{array}$ & Frequency & Percentage \\
\hline \multicolumn{3}{|l|}{ Rotation } \\
\hline $\begin{array}{l}\text { Dr. Paulino J. Garcia } \\
\text { Memorial Research and } \\
\text { Medical } \\
\text { (PJGMRMC) }\end{array}$ & 11 & 73.3 \\
\hline MV Gallego & & \\
\hline $\begin{array}{l}\text { Cabanatuan City General } \\
\text { Hospital (MVGCCGH) }\end{array}$ & 1 & 6.7 \\
\hline Eduardo L. Joson & & \\
\hline $\begin{array}{l}\text { Memorial } \quad \text { Hospital } \\
\text { (ELJMH) }\end{array}$ & 3 & 20.7 \\
\hline $\begin{array}{l}\text { Gapan District Hospital } \\
(\mathrm{GDH})\end{array}$ & 0 & 0 \\
\hline \multicolumn{3}{|l|}{ Area } \\
\hline Medical Ward & 3 & 20 \\
\hline Surgical Ward & 3 & 20 \\
\hline OB Ward & 0 & 0 \\
\hline Pediatric Ward & 0 & 0 \\
\hline Outpatient Department & 0 & 0 \\
\hline Emergency Room (ER) & 0 & 0 \\
\hline Operating Room (OR) & 8 & 53.3 \\
\hline Delivery Room (DR) & 1 & 6.7 \\
\hline $\begin{array}{l}\text { Neonatal Intensive Care } \\
\text { Unit (NICU) }\end{array}$ & 0 & 0 \\
\hline Orthopedic Ward & 0 & 0 \\
\hline \multicolumn{3}{|l|}{ Duty Schedule } \\
\hline Morning shift & 12 & 80 \\
\hline Afternoon shift & 0 & 0 \\
\hline Night shift & 3 & 20 \\
\hline
\end{tabular}

Based on table 2, the respondents preferred PJGMRMC, the base hospital, for hospital rotation that obtained $11(73.3 \%)$, OR for hospital area with 8 (53.3\%), and morning shift for duty schedule with 12 (80\%). PJGMRMC is the leading government hospital in the province of Nueva Ecija and one of the oldest hospitals in Central Luzon [9]. It has numerous services ranging from internal medicine, obstetrics and gynecology, clinical nutrition, and surgery to name a few, which provides a wide-array of exposures for students. On the other hand, a research study discovered that OR practice provided a significant contribution to student nurses' education and was effective in the determination of their career preferences after 
graduation [10]. The preference of morning shift is also similar to what a scope review found that emphasized despite considerable stress during morning shifts, nursing is more active, and there are different opportunities for learning because more people work during the day [11].

Table 3. Rate and Description of Fourth-year nursing students' core competencies at NEUST

\begin{tabular}{|c|c|c|}
\hline Core Competencies & Rate & Description \\
\hline $\begin{array}{l}\text { 1. Safety and quality } \\
\text { nursing care }\end{array}$ & 4.57 & Always \\
\hline $\begin{array}{l}\text { 2. Management of } \\
\text { resources \& environment }\end{array}$ & 4.64 & Always \\
\hline 3. Communication & 4.77 & Always \\
\hline $\begin{array}{l}\text { 4. Collaboration and team } \\
\text { work }\end{array}$ & 4.83 & Always \\
\hline 5. Health education & 4.65 & Always \\
\hline 6. Legal responsibility & 4.89 & Always \\
\hline $\begin{array}{l}\text { 7. Ethico-moral } \\
\text { responsibility }\end{array}$ & 4.84 & Always \\
\hline $\begin{array}{l}\text { 8. Personal and } \\
\text { professional development }\end{array}$ & 4.61 & Always \\
\hline 9. Quality improvement & 4.61 & Always \\
\hline 10. Research & 4.27 & Always \\
\hline 11. Record management & 4.81 & Always \\
\hline
\end{tabular}

Based on table 3, legal responsibility obtained the highest rate of 4.89 with a description of always while research having the lowest rate of 4.27. This means that the respondents always ensure competence in providing safe care by respecting the client's privacy and having documentation of care rendered to clients. Ensuring that the safety and quality of the client are performed in the health care practices are considered to be the most crucial and essential part of nursing care [12]. But, a few of the respondents do not apply research findings in nursing practice and even share research conclusions all the time. Information literacy empowers nurses to use research in their future endeavors to make meaningful and sound clinical decisions [13]. As such, it is encouraged to promote the dissemination of research findings and apply them to nursing practice.

Table 4. Rate and Description of Fourth-year nursing students' clinical learning experience at NEUST

\begin{tabular}{lll}
\hline \multicolumn{1}{c}{$\begin{array}{c}\text { Clinical Learning } \\
\text { Experience }\end{array}$} & Rate & Description \\
\hline $\begin{array}{l}\text { 1. Pedagogical } \\
\text { Atmosphere in the ward }\end{array}$ & 3.69 & Fully Agree \\
$\begin{array}{l}\text { 2. Leadership Skills of } \\
\text { Student Nurses in Peers }\end{array}$ & 3.82 & Fully Agree \\
$\begin{array}{l}\text { 3. Nursing Care in the } \\
\text { Ward }\end{array}$ & 3.82 & Fully Agree \\
$\begin{array}{l}\text { 4. Supervisory } \\
\text { Relationship } \\
\text { 5. Role of the Clinical }\end{array}$ & 3.60 & Fully Agree \\
Instructor & 3.81 & Fully Agree \\
\hline
\end{tabular}

Based on table 4, leadership skills of student nurses in peers and nursing care in the ward gained the highest rate of 3.82 with descriptions of fully agree, while supervisory relationship secured the lowest rate of 3.60. The data shows that there is an equal opportunity for each member of the team in doing group works, they educate the client regarding their health and make sure that the documentation is clear. The supervisory relationship appeared to promote positive energy, but some do not agree with receiving individual supervision. A cross sectional study concluded that the clinical learning environment and supervision contribute to the formation of professional competence in future healthcare workers [14]. It was also discovered that the supervisory connection has a substantial impact on the results of students' experiences. Hence, supervisions specifically individualized setups support the growth of students. 
Table 5. Relationship between Demographic Profile and Core Competencies of Fourth Year Nursing Students of NEUST

\begin{tabular}{|c|c|c|c|c|}
\hline \multicolumn{2}{|c|}{ Core Competencies } & \multirow{2}{*}{$\begin{array}{r}\text { Actual Age } \\
-.514^{*}\end{array}$} & \multirow{2}{*}{$\begin{aligned} \text { Sex } \\
.213\end{aligned}$} & \multirow{2}{*}{$\begin{array}{r}\text { MFI } \\
.224\end{array}$} \\
\hline SQMEAN & Pearson Correlation & & & \\
\hline & Sig. (2-tailed) & .050 & .445 & .422 \\
\hline & $\mathrm{N}$ & 15 & 15 & 15 \\
\hline \multirow[t]{3}{*}{ MREMEAN } & Pearson Correlation & -.497 & .248 & .203 \\
\hline & Sig. (2-tailed) & .060 & .373 & .467 \\
\hline & $\mathrm{N}$ & 15 & 15 & 15 \\
\hline \multirow[t]{3}{*}{ CMEAN } & Pearson Correlation & $-.560^{*}$ & .147 & .305 \\
\hline & Sig. (2-tailed) & .030 & .601 & .269 \\
\hline & $\mathrm{N}$ & 15 & 15 & 15 \\
\hline \multirow[t]{3}{*}{ CTMEAN } & Pearson Correlation & .065 & -.038 & .040 \\
\hline & Sig. (2-tailed) & .819 & .893 & .887 \\
\hline & $\mathrm{N}$ & 15 & 15 & 15 \\
\hline \multirow[t]{3}{*}{ HEMEAN } & Pearson Correlation & -.364 & .093 & .040 \\
\hline & Sig. (2-tailed) & .183 & .741 & .889 \\
\hline & $\mathrm{N}$ & 15 & 15 & 15 \\
\hline \multirow[t]{3}{*}{ LRMEAN } & Pearson Correlation & -.139 & .092 & .048 \\
\hline & Sig. (2-tailed) & .620 & .744 & .866 \\
\hline & $\mathrm{N}$ & 15 & 15 & 15 \\
\hline \multirow[t]{3}{*}{ EMRMEAN } & Pearson Correlation & -.071 & .146 & .187 \\
\hline & Sig. (2-tailed) & .803 & .604 & .505 \\
\hline & $\mathrm{N}$ & 15 & 15 & 15 \\
\hline \multirow[t]{3}{*}{ PPDMEAN } & Pearson Correlation & -.342 & -.014 & .160 \\
\hline & Sig. (2-tailed) & .212 & .962 & .568 \\
\hline & $\mathrm{N}$ & 15 & 15 & 15 \\
\hline
\end{tabular}

*Correlation is significant at the 0.05 level (2-tailed).

** Correlation is significant at the 0.01 level (2-tailed).

Based on table 5, the correlation coefficient value of age and safe and quality nursing is -0.514 with a p-value of 0.050 . Since the p-value equals the level of significance established at 0.050 , the analysis indicates that the null hypothesis is rejected, indicating that there is a significant link between real age and safe and quality nursing. Furthermore, the data indicated that the age and communication correlation coefficient value is less than the specified level of significance; hence, the null hypothesis is rejected. As a result, there is a direct relationship between real age and communication. Consequently, both of which are interpreted as a moderate negative correlation. This implies that younger respondents or respondents who belong to the common age range of fourth-year nursing students (21-25 years old) tend to have higher competencies on safe and quality nursing care and in communication than older respondents who belong to ages 26 years old and above. At the age of 25 , the brain patterns start to solidify, and they will become harder to change [15]. Individuals can still learn new things as they age, but it might take some extra effort.

Table 6. Relationship between Demographic Profile and Clinical Learning Experience of Fourth Year Nursing Students in NEUST

\begin{tabular}{|c|c|c|c|c|c|c|}
\hline \multicolumn{2}{|c|}{$\begin{array}{l}\text { Clinical Learning } \\
\text { Experience }\end{array}$} & $\begin{array}{c}\text { PA } \\
\text { MEAN }\end{array}$ & $\begin{array}{c}\text { LS } \\
\text { MEAN }\end{array}$ & $\begin{array}{l}\text { NCW } \\
\text { MEAN }\end{array}$ & $\begin{array}{c}\text { SR } \\
\text { MEAN }\end{array}$ & $\begin{array}{c}\text { RCI } \\
\text { MEAN }\end{array}$ \\
\hline \multirow{4}{*}{$\begin{array}{l}\text { Actual } \\
\text { Age }\end{array}$} & Pearson & -.306 & -.399 & -.232 & -.371 & $-.597^{*}$ \\
\hline & Correlation & & & & & \\
\hline & Sig. (2-tailed) & .268 & .140 & .406 & .174 & .019 \\
\hline & $\mathrm{N}$ & 15 & 15 & 15 & 15 & 15 \\
\hline \multirow[t]{4}{*}{ Sex } & Pearson & .156 & .284 & .215 & -.174 & .199 \\
\hline & Correlation & & & & & \\
\hline & Sig. (2-tailed) & .578 & .304 & .441 & .535 & .477 \\
\hline & $\mathrm{N}$ & 15 & 15 & 15 & 15 & 15 \\
\hline \multirow[t]{4}{*}{ MFI } & Pearson & .095 & .324 & .151 & .047 & .208 \\
\hline & Correlation & & & & & \\
\hline & Sig. (2-tailed) & .736 & .239 & .591 & .867 & .456 \\
\hline & $\mathrm{N}$ & 15 & 15 & 15 & 15 & 15 \\
\hline
\end{tabular}

Proceeding homepage: https://conferenceproceedings.ump.ac.id/index.php/pshms/issue/view/10 
*Correlation is significant at the 0.05 level (2-tailed).

** Correlation is significant at the 0.01 level (2-tailed).

Based on table 6 , the p values are greater than the level of significance set at 0.050 , analysis reveals to accept the null hypothesis. Thus, there is no significant association between demographic profile and any of the clinical learning experience parameters. This suggests that respondents' clinical learning experiences are unrelated to whether they are young or elderly, male or female, or have a low or high monthly family income. This finding is comparable to another study that identified that the age of the participants had no meaningful connection with the clinical learning experience [16]. Though it was mentioned specifically that students' learning experiences may be improved by providing preclinical orientation, defining clinical learning outline and goals to students, and regular visits and monitoring of students in the clinical context.

\section{CONCLUSIONS}

Level four nursing students showed a good standing in core competencies and clinical learning experience. Nonetheless, it was revealed that research and supervisory relationship had the lowest rate compared to other core competencies and clinical learning environment areas. Hence, research competency must be strengthened and individual supervision must be enforced.

\section{Acknowledgements}

This work was made possible by the Nueva Ecija University of Science and Technology - College of Nursing. We thank our research instructor, Zuzette B. Catabona; research adviser, Divina B. Ocampo; and dean of the CON, Dr. Jean Guillasper; for their supervision and insightful suggestions in making this study more impactful. We also acknowledge Cheena B. Mallari, research unit head, for her unrelenting support to make us, researchers, be better in what we do. We also give appreciation to Kim Jay Rivera for helping us find participants for our pilot study.

\section{REFERENCES}

[1] Saarikoski, M., Isoaho, H., Warne, T., and Leino-Kilpi, H.: 'The nurse teacher in clinical practice: developing the new sub-dimension to the Clinical Learning Environment and Supervision (CLES) Scale', Int J Nurs Stud, 2008, 45, (8), pp. 1233-1237

[2] Jamshidi, N., Molazem, Z., Sharif, F., Torabizadeh, C., and Najafi Kalyani, M.J.T.S.W.J.: 'The challenges of nursing students in the clinical learning environment: A qualitative study', 2016, 2016

[3] Yang, Y.O., Kim, M., Park, K.Y., and Yang, J.H.: 'Factors influencing the confidence in core clinical skills among hospital nurses', Int J Nurs Pract, 2015, 21, (6), pp. 831-838

[4] Ekstedt, M., Lindblad, M., and Lofmark, A.: 'Nursing students' perception of the clinical learning environment and supervision in relation to two different supervision models - a comparative crosssectional study', BMC Nurs, 2019, 18, pp. 49

[5] Khatoon, S., Sha, S.Y., Khan, A., Ali, Z., and Ali, S.A.J.O.J.o.N.: 'Assessment of clinical learning environment, supervision (CLES) among nursing students, Hyderabad, Sindh, Pakistan', 2019, 9, (04), pp. 408

[6] Kraft, M.A., Marinell, W.H., and Shen-Wei Yee, D.J.A.E.R.J.: 'School organizational contexts, teacher turnover, and student achievement: Evidence from panel data', 2016, 53, (5), pp. 1411-1449

[7] Trance, N.J.C., and Trance, L.A.M.L.: 'Embracing the K-12 curriculum: accounts of Philippine teachers and students', in Editor (Ed.)^(Eds.): 'Book Embracing the K-12 curriculum: accounts of Philippine teachers and students' (IOP Publishing, 2019, edn.), pp. 012031

[8] T. J. Bartik and B. Hershbein, "Degrees of poverty: The relationship between family income background and the returns to education," Upjohn Institute working paper, pp. 18-284, 2018.

[9] R. Vergara, "House of Representatives - House Bill No. 3889," Aiza - Amazon AWSS, 2019. [Online]. Available: https://hrep-website.s3.ap-southeast1.amazonaws.com/legisdocs/basic_18/HB09157.pdf. [Accessed: 08-Jan-2022].

[10] Yavuz van Giersbergen, M., Ozsaker, E., Dirimese, E., and Alcan, A.O.: 'The Operating Room Experiences of Nursing Students: A Focus Group Study', J Perianesth Nurs, 2016, 31, (2), pp. 146 153

[11] Ejebu, O.Z., Dall'Ora, C., and Griffiths, P.: 'Nurses' experiences and preferences around shift patterns: A scoping review', PLoS One, 2021, 16, (8), pp. e0256300 
[12] J. Johnson, "What is quality and safety in nursing?," GCU, 14-Feb-2018. [Online]. Available: https://www.gcu.edu/blog/nursing-health-care/what-quality-and-safety-nursing. [Accessed: 08-Jan2022].

[13] B. F. Schloman, "Information Resources: Information Literacy: The Benefits of Partnership," WHY DO NURSES NEED RESEARCH?, 12-Sep-2017. [Online]. Available: https://nursingonline.nsuok.edu/degrees/rn-to-bsn/why-nurses-need-research/. [Accessed: 08-Jan2022].

[14] Pitkanen, S., Kaariainen, M., Oikarainen, A., Tuomikoski, A.M., Elo, S., Ruotsalainen, H., Saarikoski, M., Karsamanoja, T., and Mikkonen, K.: 'Healthcare students' evaluation of the clinical learning environment and supervision - a cross-sectional study', Nurse Educ Today, 2018, 62, pp. 143-149

[15] Arain, M., Haque, M., Johal, L., Mathur, P., Nel, W., Rais, A., Sandhu, R., and Sharma, S.: 'Maturation of the adolescent brain', Neuropsychiatr Dis Treat, 2013, 9, pp. 449-461

[16] Gemuhay, H.M., Kalolo, A., Mirisho, R., Chipwaza, B., Nyangena, E.J.N.R., and Practice: 'Factors affecting performance in clinical practice among preservice diploma nursing students in Northern Tanzania', 2019, 2019 